\title{
Screening yeast strains for alcohol fermentation from the dried traditional yeast
}

\author{
Pham Nguyen Phuong Thao ${ }^{1 *}$, Bui Thi Thanh Thuy ${ }^{1}$, Le Bui Trung Trinh ${ }^{1}$, \\ Nguyen My Phi Long ${ }^{1}$ \\ ${ }^{1}$ University of Science, Vietnam National University Ho Chi Minh City, Vietnam \\ *Corresponding author: pnpthao@hcmus.edu.vn
}

\begin{tabular}{|c|c|}
\hline ARTICLE INFO & ABSTRACT \\
\hline $\begin{array}{l}\text { DOI:10.46223/HCMCOUJS. } \\
\text { tech.en.8.1.908.2018 }\end{array}$ & $\begin{array}{l}\text { Methods to produce rice alcohol by dried traditional yeast } \\
\text { are unstable because the yeast system in dried traditional yeast has } \\
\text { depended on nature and has not been controlled. In this study, a } \\
\text { total of } 15 \text { different kinds of dried traditional yeast were prepared } \\
\text { and screened. Each yeast strain was evaluated by analyzing its }\end{array}$ \\
\hline Received: February $6^{\text {th }}, 2018$ & fermentation property and alcohol tolerance. There are 19 yeast \\
\hline Revised: March 30"th 2018 & $\begin{array}{l}\text { strains were isolated and their growth conditions and ethanol- } \\
\text { producing properties were examined. Results showed that three }\end{array}$ \\
\hline Accepted: April $16^{\text {th }}, 2018$ & $\begin{array}{l}\text { strains } \mathrm{S} 1, \mathrm{BT}, \mathrm{BL} 3 \text { grew and produced ethanol at temperature } 28- \\
30^{\circ} \mathrm{C} \text {, and } \mathrm{pH} 5-5.5 \text {. Especially, the high concentration ethanol } \\
\text { tolerance ability of the three strains was at } 8-18 \% \text {. Our results }\end{array}$ \\
\hline $\begin{array}{l}\text { Keywords: } \\
\text { rice alcohol, the dried } \\
\text { traditional yeast, yeast }\end{array}$ & $\begin{array}{l}\text { showed that these strains were valuable microorganisms and could } \\
\text { be utilized as a basis for further study of dried traditional yeast in } \\
\text { traditional alcoholic beverages. }\end{array}$ \\
\hline
\end{tabular}

\section{Introduction}

As society grows, there is a strong demand for a variety of delicious and national representative wines. Moreover, it has to be ensured that this wine is safe for users. If Japan is proud of its Sake (Iwata, Suzuki, \& Aramaki, 2003), Korea has Sochou or Western European countries has Vodka (Russia) and Whiskey (Scotland), rice alcohol is considered as an alcoholic beverage commonly used in Vietnam basing on its wet rice civilization. There is no accurate record of how Vietnam's traditional alcohol was made. However, it has been known from ancient times that rice alcohol has been used extensively in holidays, festivals, sacrifices and even in regular meals.

Alcohol in Vietnam is produced in many different ways. Each area in Vietnam has a distinct taste of alcohol such as Mau Son-Lang Son, Dao - Yen Bai, Bau Da - Binh Dinh, Go Den - Long An. The traditional method to produce alcohol using dried yeast is still widely applied, although the efficiency and the product in many regions are still unstable. This instability is due to the microorganisms present in the dried yeast without being controlled. They play an important role in transforming substances from raw materials into sugars and then 
to liquors through the saccharification process and fermentation. They make a significant influence on food quality parameters such as taste, texture and nutritious value (Kofi, Nout, \& Sarkar, 2006). There are various types of yeast involved in the production of alcohol such as Hanseniaspora, Candida, Metschnikowia... (Ray, 2001; Schutz \& Gafner, 1993). Especially, Saccharomyces strains are used the majority in many fermentation processes (Dung, Rombouts, \& Nout, 2007).

Around the world, there were several research on selecting high activity yeast strains for alcohol fermentation. A study of F. Noé Arroyo-López et al. done in 2009 examined the effects of heat, $\mathrm{pH}$ and concentration of sugar on 3 strains of $S$. cerevisiae T73, S. Kudriavzevii IFO 1802 T and hybrid strain S. cerevisiae $\times$ S. kudriavzevii W27 used in winemaking. In particular, the W27 hybrid strain has the ability to ferment into alcohol at high $\mathrm{pH}(5,5)$ and low sugar concentration (10g/l). T73 and W27 could be used in industrial production. In 2011, H. Yamamoto isolated 7 yeast strains with high alcohol fermentation activity and Shochu flavor. Particularly, the MF062 strain had highly fermentable activity, high yield, incense and heat tolerance. The results of genetic and phylogenetic data show that MF062 is Saccharomyces cerevisiae but has many different characteristics from industrial yeasts using in shochu production. In this year, Yeon-Ju Lee1 et al. surveyed the ability of alcohol and osmotic pressure tolerance of different yeast strains using maltose and hydrolysis of starch. In the 637 presumed yeast species, 115 strains showed good growth in yeast-peptone-dextrose containing $30 \%$ dextrose, $7 \%$ alcohol, or $2 \%$ maltose, and produced $5 \alpha$-amylase enzymes. Analyzing the nucleotide sequence of the 26S rDNA gene classified these yeast strains into 13 species of five genera: Pichia anomala was the most common (41.7\%), Wickerhamomyces (19.2\%), P. guilliermondii (15\%), Candida spp. (5.8\%), Kodamaea ohmeri (2.5\%) and Metschnikowia spp. (2.5\%). The isolation NK28, identified as Saccharomyces cerevisiae, had all the desired properties for the purposes of this study, except for the production of $\alpha$-amylase but the ability to ferment the wine better than commercial wine yeast counterpart. Another study, conducted in 2015, evaluated the fermentation efficiency in producing vodka from the potato of three strains Saccharomyces cerevisiae. Results showed that bread yeast was most effective in the medium supplemented with hydrolyzed potatoes and sucrose (17\% by weight): substituting substrates into high yields (each gram sugar lost, $0.47 \mathrm{~g}$ ethanol created), high fermentation product $(91.4 \%)$, high ethanol content $(6.05 \% / \mathrm{V})$.

In Vietnam, there were many reports about yeast for producing alcohol isolated from different sources of raw materials like starch from the rice. In 2009, Ngo Thi Phuong Dung surveyed the fermentation and alcoholic tolerance of different yeast strains. From 50 germs isolated from wine yeast, 9 yeast lines with fast and strong fermentation in glucose solution after 14 hours of fermentation were selected. 9 broths of yeast collected from fermentation in reducing sugar solution were able to use and almost completely alter sugar reduction at $18 \%$ (w/v). Also, this yeast could produce ethanol with a concentration of $8.3-8.6 \%(\mathrm{w} / \mathrm{v})$. The project also determined the alcoholic beverage of yeast strain $\mathrm{s}$ and found that these seven yeast strains of Saccharomycesbelonged to Ascomycetes. Another research on the production of some traditional wine from rice had been done by engineer Nguyen Dinh Quy from 2010-2012. The results indicated that currently, locally available microorganisms contained three main groups: 
mold, yeast, and imitation yeast. The author selected four strains suitable for yeast production. The research has developed a technological process to manufacture enzymes with highly enzymatic, alpha-amylase activity at $1102 \mathrm{U} / \mathrm{g}$ and glucoamylase at $241 \mathrm{U} / \mathrm{g}$. Also in 2012, the research team led by Nguyen Huu Thanh et al. conducted a number of studies on biological characteristics and identified yeast that was isolated from the dry traditional yeast in the Cuu Long Delta. 128 strains were isolated with 30 strains tolerate temperature at $50^{\circ} \mathrm{C}$ and alcohol tolerance of $17 \mathrm{ml} / \mathrm{l}$. Sequencing was done in 10 strains, 7 strains were identified as Saccharomyces cerevisiae, 3 strains were Clavispora Iusitaniae. Complete the technology and equipment of traditional rice wine production with 800,000 1/year. To be conducted in 2013 2015 by Dr. Nguyen Viet Anh as the director. The project had completed the process of technology production of industrial rice wine which increased from 300,000 liters per year to 800,000 liters per year. Rice wine product reached good quality, stable, aromatic similar to the traditional rice wine, no toxic impurities, harmful. Designing and manufacturing mold production equipment scale of $1,500 \mathrm{~kg} / \mathrm{batch}$ replaced manual mold culture, passive, easy to contaminate. In addition, the project has developed the technological process and production model of fermented rice vinegar by submerged fermentation using waste by-products of the process of producing industrial rice wine. The quality of the vinegar produced was much higher $(8 \%)$ than the surface fermentation, characteristic aroma, short fermentation time. The project was accepted on 24.6.2016 with excellent results.

Therefore, the aim of this study was to select yeast strains with the high alcoholfermented ability and investigate optimum conditions for alcohol fermentation.

\section{Materials and methods}

\subsection{Isolation and identification of yeast strains}

The fifteen different dried traditional yeast were collected from Long An market, Go Den market and Cho Lon market $\rightarrow$ enriched in liquid Hansen medium (pepton $10 \mathrm{~g} / 1, \mathrm{MgSO}_{4}$ $3 \mathrm{~g} / 1, \mathrm{KH}_{2} \mathrm{SO}_{4} 3 \mathrm{~g} / 1$, glucose $50 \mathrm{~g} / \mathrm{l}$ ) (Use a scalpel knife to remove the powder in the middle of the dried traditional yeast) incubated for $24 \mathrm{hrs}$ at $28-30^{\circ} \mathrm{C} \rightarrow$ Isolated by streaking on Hansen agar plates $\rightarrow$ selecting individual characteristic colonies to purify by streaking on Hansen agar and stored.

The yeast strains were identified to genus based on their morphological characteristics and the bud forming and spore-forming with the classification key of Kurtzman and Fell (1998) (Kurtzman \& Fell, 1998).

All isolated yeast strains were stored in Hansen medium containing $40 \%$ glycerol at $30^{\circ} \mathrm{C}$.

\subsection{Investigation of fermentation property of yeast strains}

The fermentation test of 19 strains was conducted in a molasses medium with a concentration of $15 \%$ sucrose. $30 \mathrm{ml}$ yeast biomass $\left(10^{8}\right.$ cell $\left./ \mathrm{ml}\right)$ was added in $300 \mathrm{ml}$ molasse medium, incubated at $20^{\circ} \mathrm{C}$. The speed of $\mathrm{CO}_{2}$ generation of strains was determined through the volume of $\mathrm{CO} 2$ produced in the falcon tube upside down by the time. The yeast strain has 
a faster fermentation capacity is the yeast strain that produces higher volume columns over time.

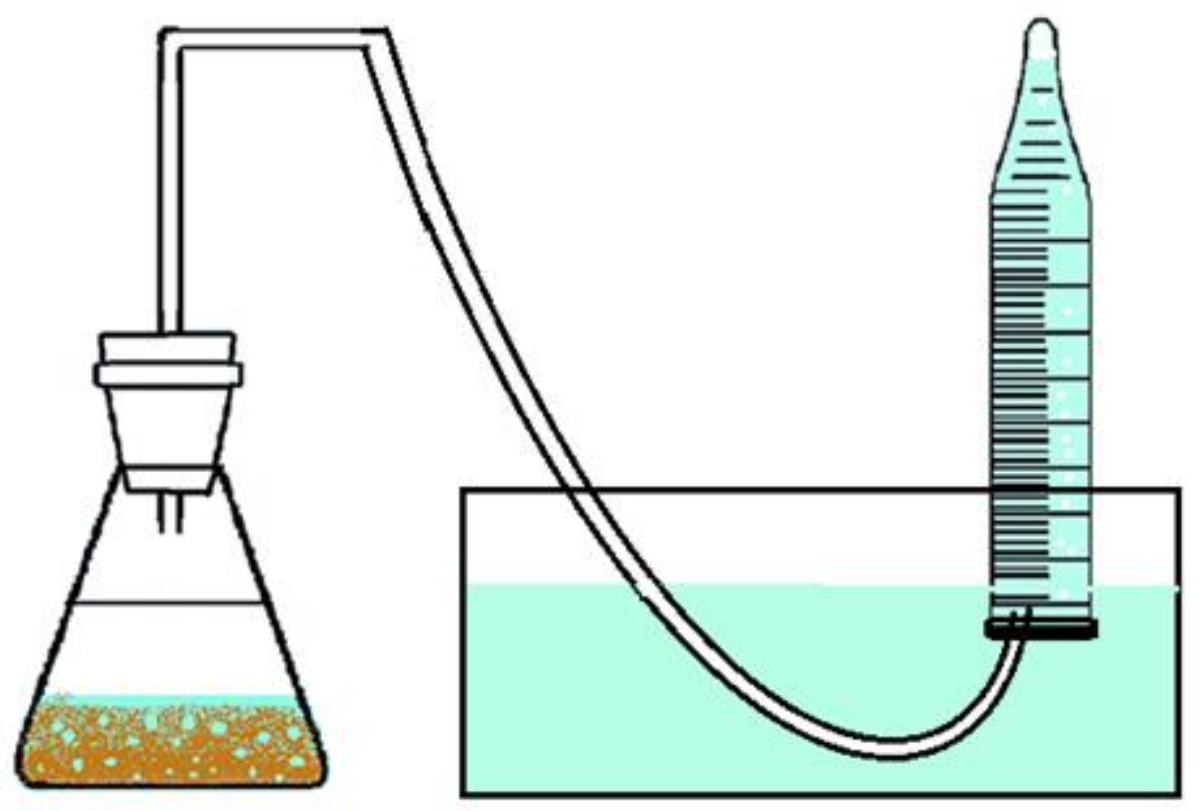

Figure 1. System diagram used to determine the speed of $\mathrm{CO} 2$ generated in Fermentation properties test

\subsection{Investigation of ethanol tolerance of yeast strains}

Test tubes containing $5 \mathrm{ml}$ of liquid Hansen medium were sterilized at $121^{\circ} \mathrm{C}$ for 15 minutes. Ethanol was added to the medium with corresponding concentrations of $8 \%, 10 \%$, $12 \%, 14 \%, 16 \%, 18 \%, 20 \% .1 \mathrm{ml}$ biomass $\left(10^{8}\right.$ cells $\left./ \mathrm{ml}\right)$ of 19 strains were inoculated into 19 test tubes, incubated at room conditions. After $24 \mathrm{hrs}$, the effervescence in test tubes was recorded and this solution of yeast was streaked on Hansen agar plate to verify for effervescence is due to the fermentation of yeast through the ability to form colonies. The yeast strains produced gar in high alcohol medium and form colonies on the agar plate was the ethanol tolerance strains.

\subsection{Investigation of optimum conditions for alcohol fermentation}

To survey of optimum initial $\mathrm{pH}$ for the fermentation, $10 \%$ volume yeast $\left(10^{7}\right.$ cells $\left./ \mathrm{ml}\right)$ was inoculated in each erlen containing $200 \mathrm{ml}$ liquid Hansen medium with different $\mathrm{pH}$ values of $4.0,4.5,5.0,5.5$ and 6.0 ; incubated at $28^{\circ} \mathrm{C}$ for $24 \mathrm{hrs}$.

Optimal sucrose concentration was determined by adding $10 \%$ volume yeast solutions $\left(10^{7}\right.$ cells $\left./ \mathrm{ml}\right)$ in erlens containing $200 \mathrm{ml}$ liquid Hansen medium with different sucrose concentrations of $5 \%, 7 \%, 9 \%, 11 \%, 13 \%, 15 \%, 17 \%, 19 \%$ and $21 \%$; incubated at $28^{\circ} \mathrm{C}$ for $120 \mathrm{hrs}$. 
To study the effect of temperature on the fermentation, $10 \%$ volume yeast $\left(10^{7}\right.$ cells $\left./ \mathrm{ml}\right)$ was inoculated erlens with $200 \mathrm{ml}$ liquid Hansen medium, incubated for $24 \mathrm{hrs}$ at different temperatures of $26^{\circ} \mathrm{C}, 28^{\circ} \mathrm{C}, 30^{\circ} \mathrm{C}$ and $32^{\circ} \mathrm{C}$.

After the incubation time, alcohol in experiment samples was distilled by fractional distillation and alcohol concentration was determined by alcoholmeter. For the experiment to determining the suitable sucrose concentration for fermentation, the total remaining sugar was evaluated after fermentation by Phenol-Sulphuric acid method (Nielsen, 2010). All tests are repeated 2 times independently and each time, a sample is made. The result is the average value of two times the experiment and Standard deviation.

\section{Results and discussion}

\subsection{Results of isolation and identification}

Based on morphological characteristics (Table 1, Figure 2, Figure 3), 19 isolated strains belong to the genus Saccharomyces. They had multilateral budding, produced little or no acetic acid. Ascospores were formed and asci were globose. Gelatin media was not strongly liquefied, and the strains were not assimilated nitrate.

\section{Table 1}

Characteristics of cells and colonies of cultured yeast in liquid Hansen media

\begin{tabular}{|c|c|c|c|l|}
\hline STT & $\begin{array}{c}\text { Strain } \\
\text { code }\end{array}$ & $\begin{array}{c}\text { Cell } \\
\text { shape }\end{array}$ & $\begin{array}{c}\text { Cell size } \\
(\mu \mathrm{m})\end{array}$ & \multicolumn{1}{|c|}{ Colony shape } \\
\hline 1 & AD & $\begin{array}{c}\text { Small } \\
\text { oblong }\end{array}$ & $2,0 \times 5,0$ & $\begin{array}{l}\text { yellowish-white, dry, rounded margin, high rise, } \\
\text { the smell of alcohol, size 3 mm. }\end{array}$ \\
\hline 2 & S1 & Oblong & $1,5 \times 5,5$ & $\begin{array}{l}\text { yellowish-white, rounded margin, high rise, the } \\
\text { smell of alcohol, size 2-3 mm. }\end{array}$ \\
\hline 3 & TN & Oval & $1,5 \times 3,5$ & $\begin{array}{l}\text { Ivory white, dry, rounded margin, high rise, size 2- } \\
\text { 3 mm }\end{array}$ \\
\hline 5 & TH & Obovoid & $3,0 \times 5,0$ & $\begin{array}{l}\text { Slightly yellow, rounded, small size, high rise, } \\
\text { wrinkle margin, size 3 mm. }\end{array}$ \\
\hline 6 & BC1.1 & Oval & $2,0 \times 4,0$ & $\begin{array}{l}\text { Large size, powdered, dry, high rise, wrinkle } \\
\text { margin, centered in the middle, odorless, size } \\
\text { 5mm. }\end{array}$ \\
\hline 7 & BC1.2 & Oval & $1,5 \times 3,5$ & $\begin{array}{l}\text { White, large size, powdered, high rise, wrinkle } \\
\text { margin, Odoriferous, size 4-5 mm }\end{array}$ \\
\hline 8 & Oval & $3,5 \times 5,5$ & $\begin{array}{l}\text { White, rounded margin, high rise, slightly mucus, } \\
\text { odorless, size 2-3 mm }\end{array}$ \\
\hline
\end{tabular}




\begin{tabular}{|c|c|c|c|c|}
\hline STT & $\begin{array}{l}\text { Strain } \\
\text { code }\end{array}$ & $\begin{array}{c}\text { Cell } \\
\text { shape }\end{array}$ & $\begin{array}{c}\text { Cell size } \\
(\mu \mathrm{m})\end{array}$ & Colony shape \\
\hline 9 & BL1 & Oval & $4,5 \times 5,0$ & $\begin{array}{l}\text { White, high rise, wrinkle margin, centered in the } \\
\text { middle, mucus, odoriferous, size } 5-6 \mathrm{~mm} \text {. }\end{array}$ \\
\hline 10 & BL2 & Oblong & $2,0 \times 5,0$ & $\begin{array}{l}\text { White, high rise, small size, rounded margin, } \\
\text { mucus, odoriferous, size } 2-3 \mathrm{~mm}\end{array}$ \\
\hline 11 & BL3 & Spherical & $2,0 \times 3,5$ & $\begin{array}{l}\text { Milky, high rise, wrinkle margin, dry, odoriferous, } \\
\text { size } 3-4 \mathrm{~mm} \text {. }\end{array}$ \\
\hline 12 & $\mathrm{BC} 2.1$ & Oval & $1.5 \times 3,5$ & $\begin{array}{l}\text { White, small size, high rise, wrinkle margin, dry, } \\
\text { odorless, size } 2-3 \mathrm{~mm} \text {. }\end{array}$ \\
\hline 13 & BC2.2 & Oval & $2,5 \times 4,5$ & $\begin{array}{l}\text { Milky, wrinkle margin, centered in the middle, } \\
\text { dry, odorless, size } 2-3 \mathrm{~mm} \text {. }\end{array}$ \\
\hline 14 & $\mathrm{BC} 2.3$ & Oblong & $2,0 \times 6,0$ & $\begin{array}{l}\text { White, centered in the middle, dry, the margin has } \\
\text { roots, size } 5-6 \mathrm{~mm} \text {. }\end{array}$ \\
\hline 15 & $\mathrm{MB}$ & Oval & $2,5 \times 5,0$ & $\begin{array}{l}\text { Slightly milky, rounded margin, mucus, the smell } \\
\text { of alcohol, size } 3-5 \mathrm{~mm} \text {. }\end{array}$ \\
\hline 16 & $\mathrm{TH}$ & Oblong & $2,0 \times 4,0$ & $\begin{array}{l}\text { Yellowish white, small size, hight rise, wrinkle } \\
\text { margin, the smell of alcohol, size } 3 \mathrm{~mm}\end{array}$ \\
\hline 17 & BC3 & Oblong & $2,5 \times 4,5$ & $\begin{array}{l}\text { White, small size, high rise, mucus, centered in the } \\
\text { middle, odorless, size } 2-3 \mathrm{~mm} \text {. }\end{array}$ \\
\hline 18 & $\mathrm{HN}$ & $\begin{array}{c}\text { Small } \\
\text { oval }\end{array}$ & $3,0 \times 3,5$ & $\begin{array}{l}\text { Yellowish white, large size, rounded margin, high } \\
\text { rise, mucus, the smell of alcohol, size } 5 \mathrm{~mm} \text {. }\end{array}$ \\
\hline 19 & BT & Spherical & $4.5 \times 5,5$ & $\begin{array}{l}\text { Slightly milky, centered in the middle, rounded } \\
\text { margin, dry, smell of alcohol, size } 5 \mathrm{~mm} \text {. }\end{array}$ \\
\hline 20 & $\mathrm{TX}$ & Spherical & $2,5 \times 5,0$ & $\begin{array}{l}\text { Milky white, high rise, small size, dry, rounded } \\
\text { margin, odorless, size } 2-3 \mathrm{~mm} \text {. }\end{array}$ \\
\hline
\end{tabular}

Source: The researcher's data analysis 


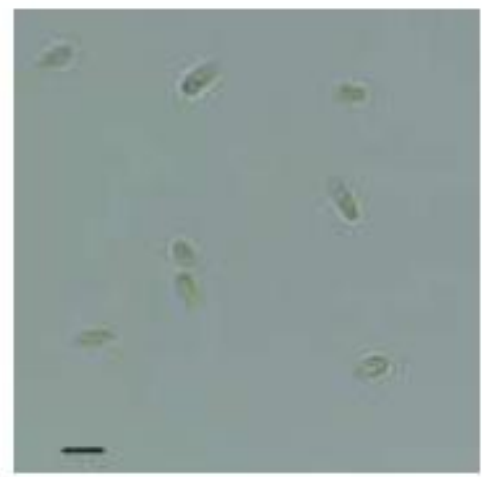

BC23: Oblong

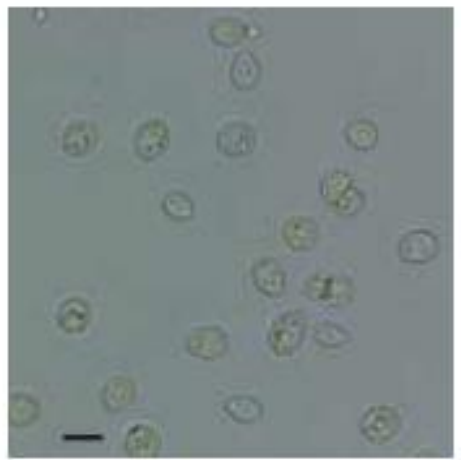

HG: Obovoid

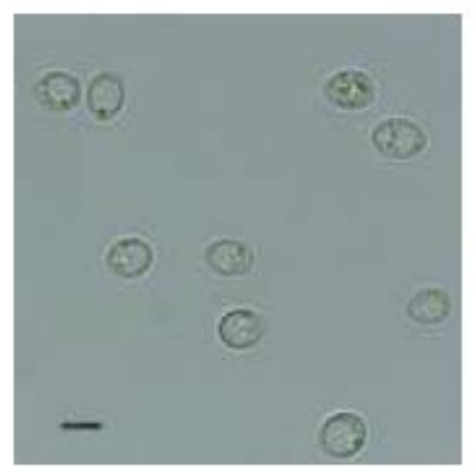

BL1: Oval

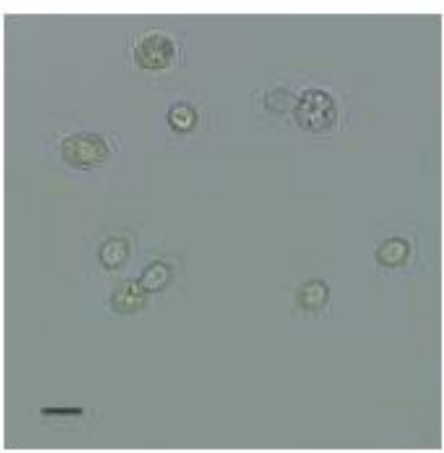

HN: Small oval

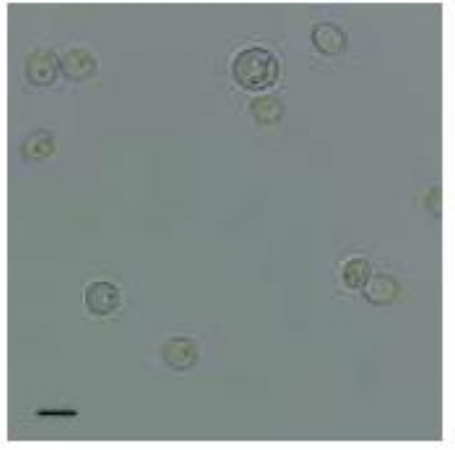

BT: Spherical

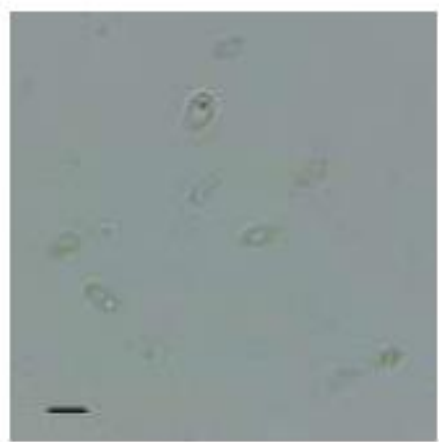

AD: Small oblong

Figure 2. Types of morphological characteristics of isolated strains in liquid hansen media. Scale bar $5 \mu \mathrm{m}$

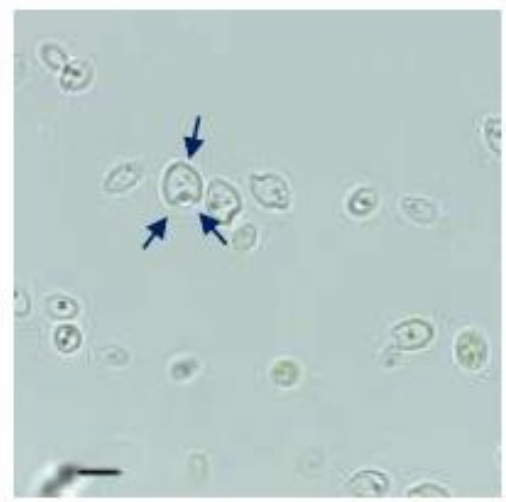

$\mathrm{BC} 3$

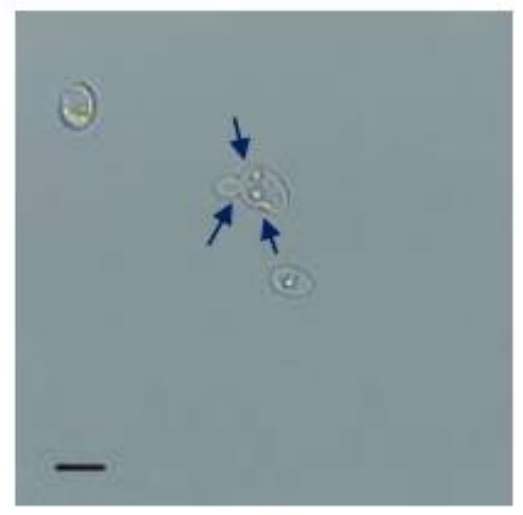

BL2

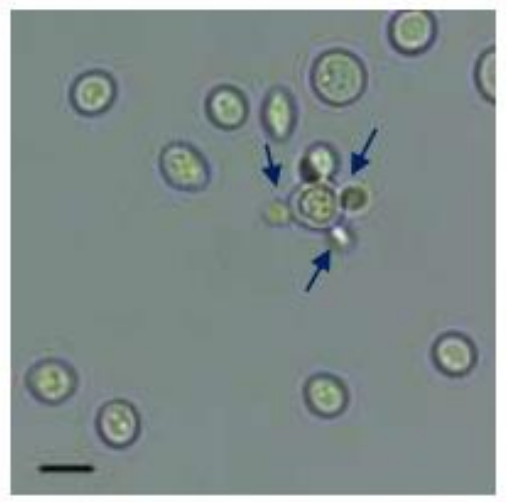

BT

Figure 3. Location of yeast bud scars in (arrow) liquid hansen media for 20 days. Scale bar 5 $\mu \mathrm{m}$ 

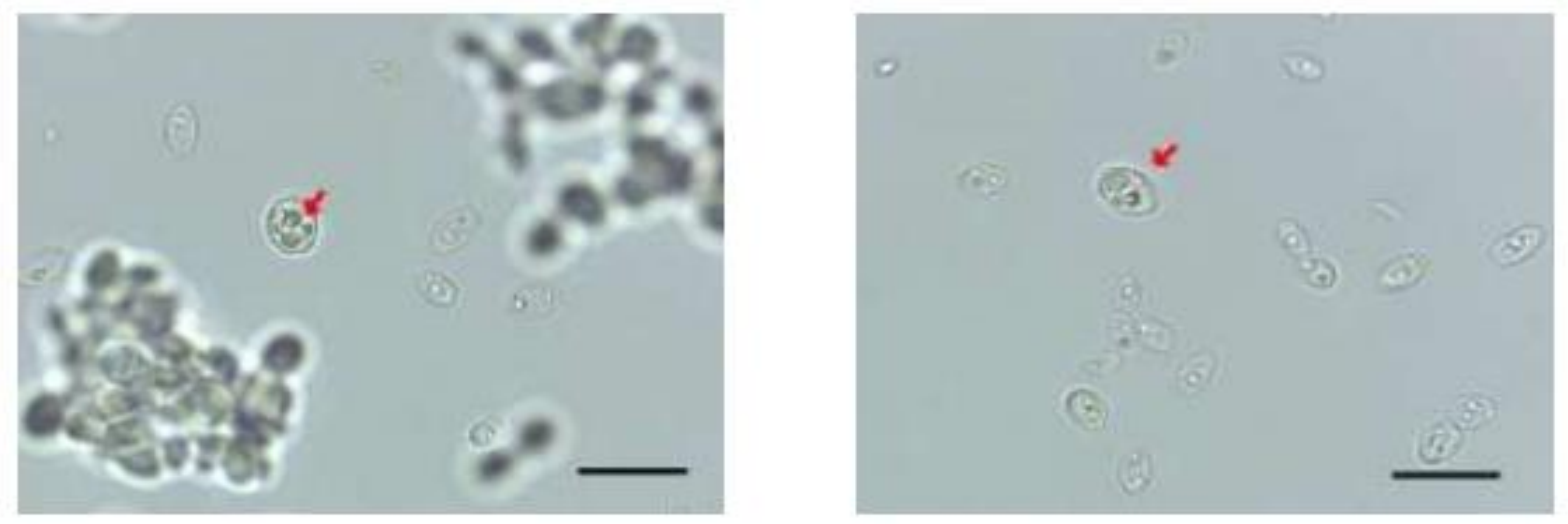

Figure 4. Morphological characteristics of asci with 4 ascospores of the yeast strain BC2.2 (arrow). Scale bar $10 \mu \mathrm{m}$
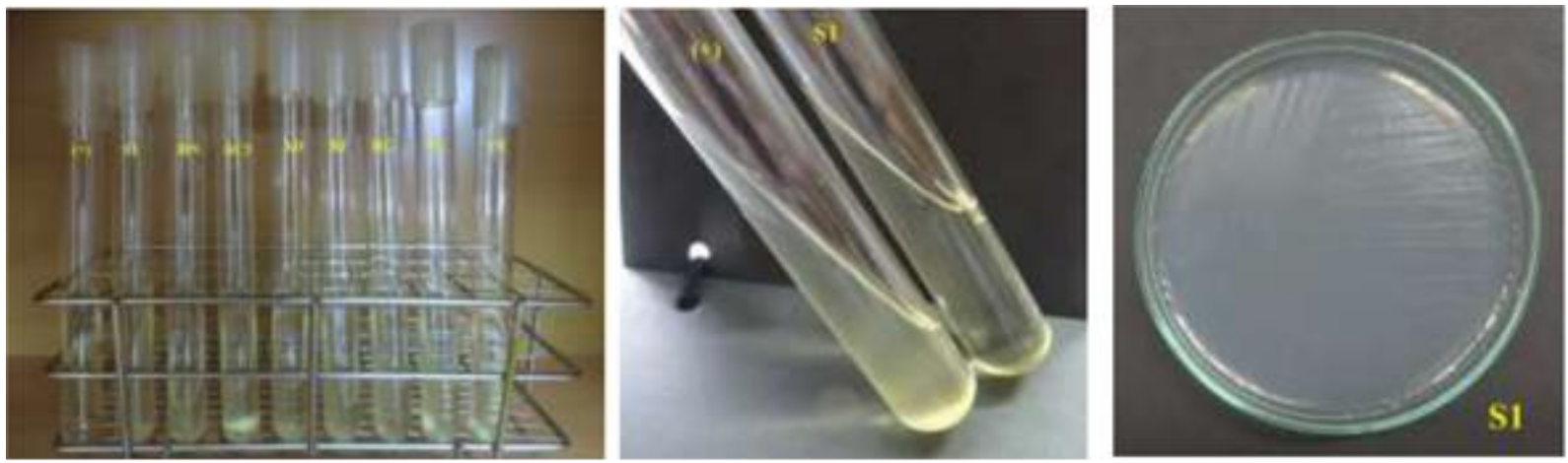

Figure 5. A: Gelatin medium was not strongly liquefied by growth of yeast strains. B: compared to the control sample (+), the $\mathrm{S} 1$ strain formed turbid solution in the tube but gelatin was not liquefied at $20^{\circ} \mathrm{C}, \mathrm{C}$ : the strain S1 did not grow on Bacto-Yeast Carbon base media added Nitrate

Note: The control sample (+) is Gelatin medium

\subsection{Fermentation property and ethanol tolerance of yeast strains}

The starting time of fermentation is different between 19 yeast strains even they were inoculated in the same condition. Among them, 3 strains S1, BL3, BT had the earliest fermentation time 83 mins, 89 mins and 99 mins, respectively (Figure 6). 


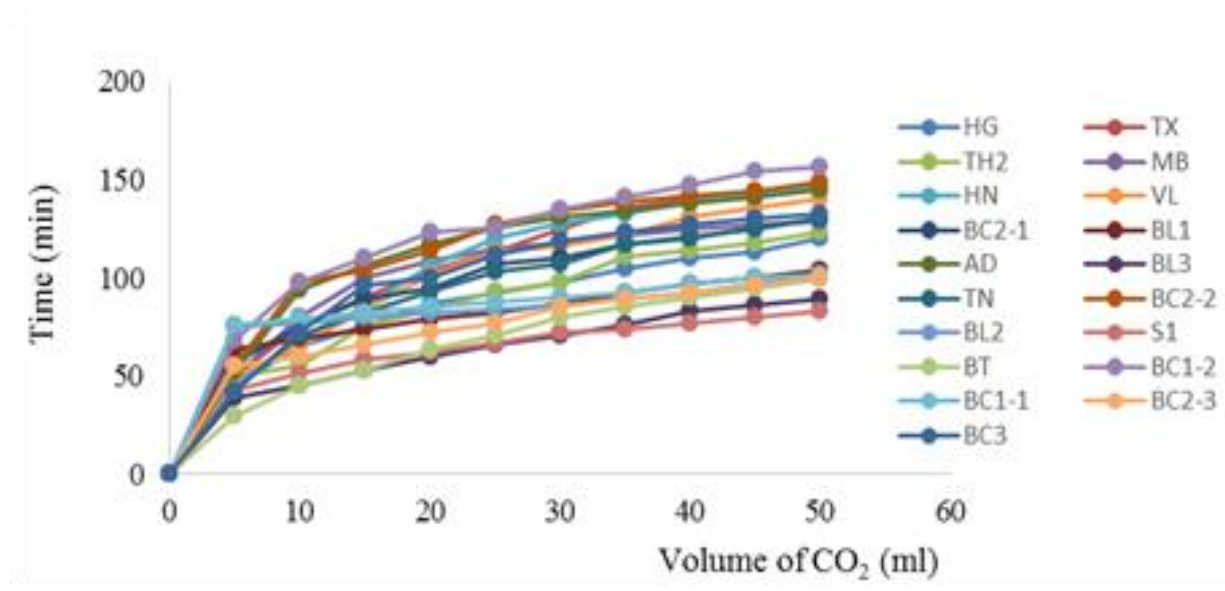

Figure 6. The $\mathrm{CO}_{2}$ generation speed of yeast strains

According to Brown, Oliver, Harrison, \& Righelato (1981), ethanol inhibits both growth and fermentation of yeasts (Kunkee \& Bisson, 1993; Reed \& Nagodawithana, 1991). This study determined ethanol tolerance of the isolated strains by producing biomass and $\mathrm{CO}_{2}$ gas in the test tube (Table 2), then they were streaked on agar plates for verification (Figure 7). Results showed that the biomass of yeast decreases as the concentration of ethanol in the solution increases. At concentrations of ethanol $8 \%$ to $14 \%$, the biomass was obtained from 19 strains. At a concentration of ethanol $18 \%$, only a few yeast strains grew. Particularly with $20 \%$ ethanol concentration, no strains survived. Ethanol might inhibit the metabolic capacity of yeast.

\section{Table 2}

Alcohol tolerance of yeast strains

\begin{tabular}{|c|c|c|c|c|c|c|c|}
\hline \multirow{2}{*}{ Strain } & \multicolumn{7}{|c|}{ Alcohol content (\%) } \\
\cline { 2 - 8 } & $\mathbf{8}$ & $\mathbf{1 0}$ & $\mathbf{1 2}$ & $\mathbf{1 4}$ & $\mathbf{1 6}$ & $\mathbf{1 8}$ & $\mathbf{2 0}$ \\
\hline $\mathrm{BT}$ & + & + & + & + & + & - & - \\
\hline $\mathrm{TN}$ & + & + & + & + & - & - & - \\
\hline $\mathrm{BC} 2.3$ & + & + & + & + & - & - & - \\
\hline $\mathrm{AD}$ & + & + & + & + & + & + & - \\
\hline $\mathrm{HN}$ & + & + & + & + & + & + & - \\
\hline $\mathrm{BC} 1.1$ & + & + & + & + & + & - & - \\
\hline $\mathrm{BC} 3$ & + & + & + & + & + & + & - \\
\hline $\mathrm{S} 1$ & + & + & + & + & + & + & - \\
\hline $\mathrm{BL} 2$ & + & + & + & + & - & - & - \\
\hline $\mathrm{V} 1$ & + & + & + & + & + & - & - \\
\hline $\mathrm{BL} 3$ & + & + & + & + & + & - & - \\
\hline
\end{tabular}




\begin{tabular}{|c|c|c|c|c|c|c|c|}
\hline \multirow{2}{*}{ Strain } & \multicolumn{7}{|c|}{ Alcohol content (\%) } \\
\cline { 2 - 8 } & $\mathbf{8}$ & $\mathbf{1 0}$ & $\mathbf{1 2}$ & $\mathbf{1 4}$ & $\mathbf{1 6}$ & $\mathbf{1 8}$ & $\mathbf{2 0}$ \\
\hline $\mathrm{BC} 2.1$ & + & + & + & + & + & - & - \\
\hline $\mathrm{BC} 2.2$ & + & + & + & + & - & - & - \\
\hline $\mathrm{HG}$ & + & + & + & + & + & - & - \\
\hline $\mathrm{BL} 1$ & + & + & + & + & - & - & - \\
\hline $\mathrm{MB}$ & + & + & + & + & - & - & - \\
\hline $\mathrm{TX}$ & + & + & + & + & + & - & - \\
\hline $\mathrm{TH}$ & + & + & + & + & - & - & - \\
\hline $\mathrm{BC} 1.2$ & + & + & + & + & - & - & - \\
\hline
\end{tabular}

Note: +: biomass and $\mathrm{CO}_{2}$, -: non biomass and $\mathrm{CO}_{2}$

Source: The researcher's data analysis
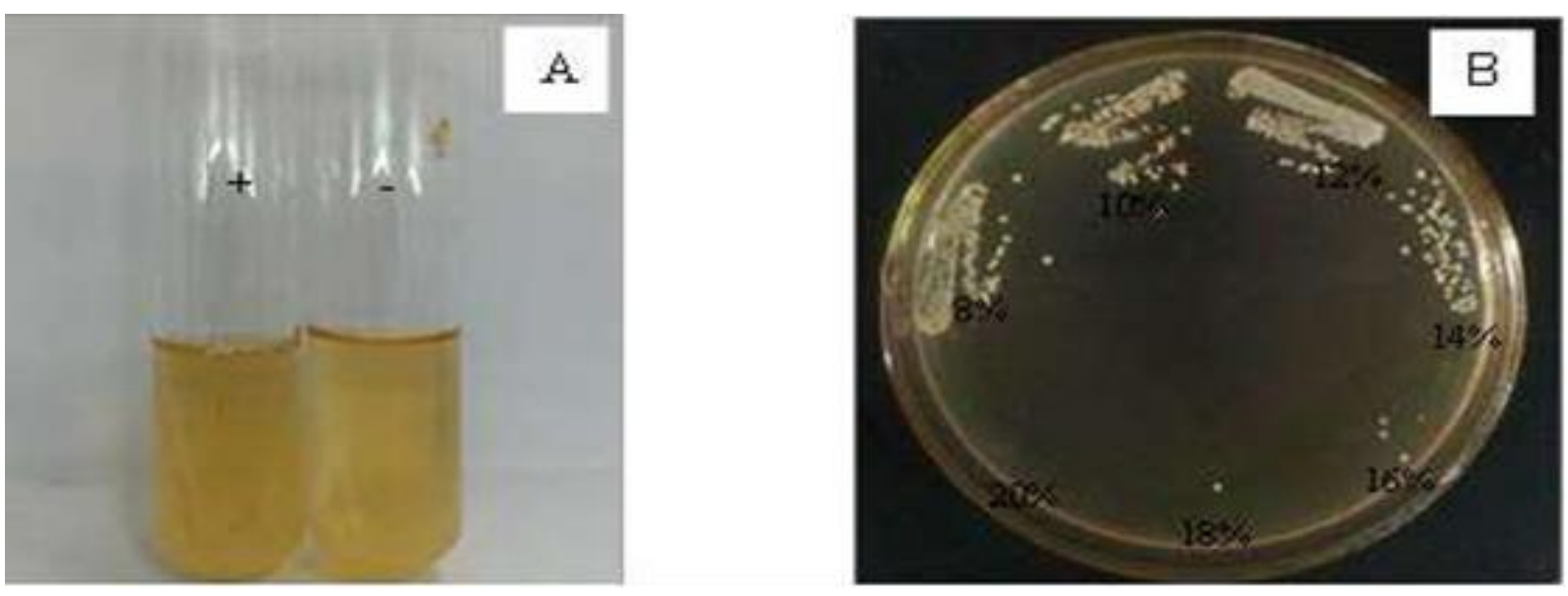

Figure 7. The alcohol tolerance of yeast. (A) $\mathrm{CO}_{2}$ produced in test tube, (B) the growth of yeast biomass on agar plate for verification

\subsection{Optimum conditions for alcohol fermentation}

Based on the fermentation property and high ethanol tolerance, three strains S1, BT, BL3 were chosen in the next experiments.

\subsubsection{Effect of initial $\mathrm{pH}$ on alcohol fermentation}

This study evaluated the effect of initial $\mathrm{pH}$ on the fermentation. The optimum $\mathrm{pH}$ was determined by measuring the alcohol concentration after $24 \mathrm{hrs}$ incubated at $28^{\circ} \mathrm{C}$. The highest concentration of alcohol was found t at $\mathrm{pH} 5$ to 5.5, depending on the strain (Figure 8). At a pH of 4 or 6 , the alcohol concentration was lower. 


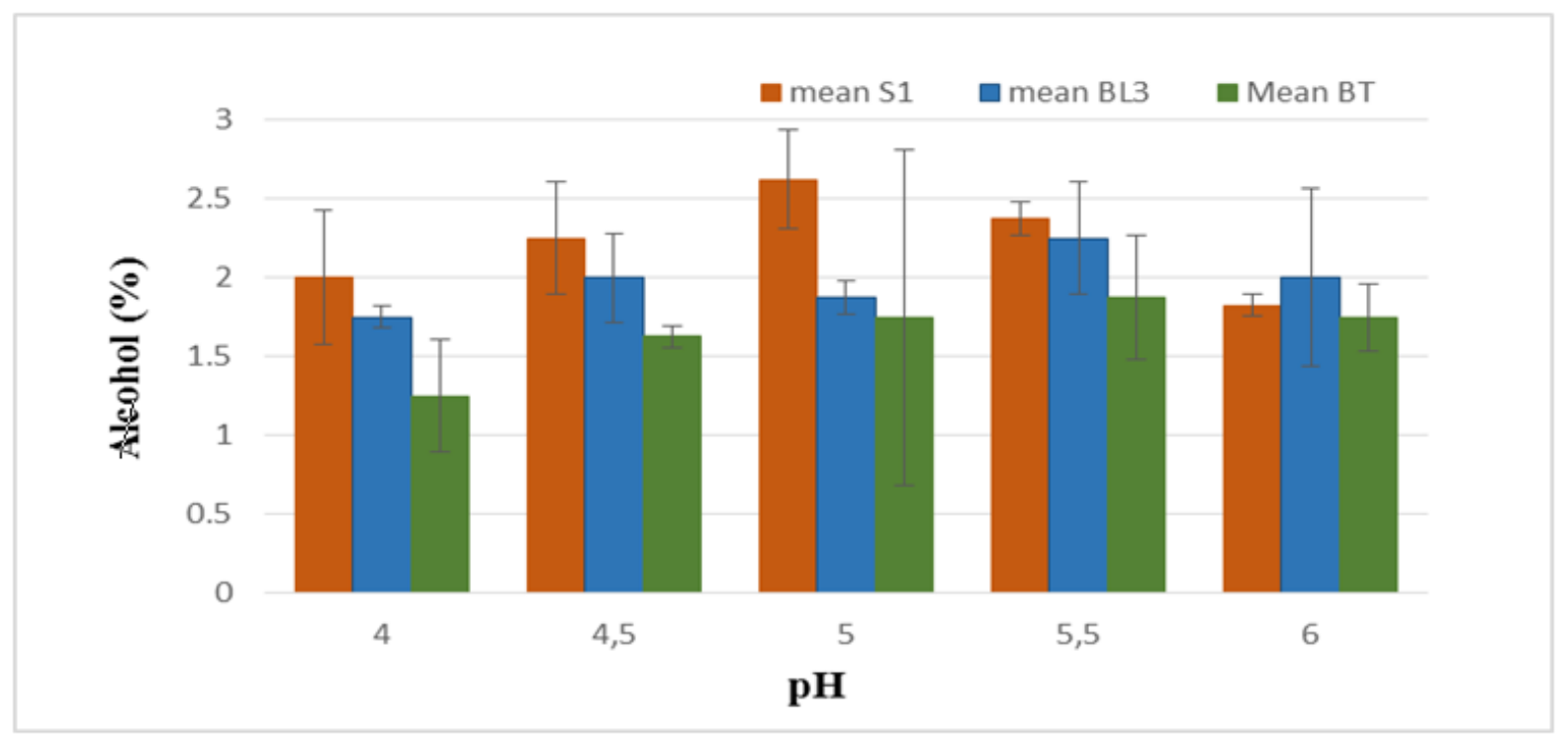

Figure 8. Effect of $\mathrm{pH}$ on the production of alcohol of three strains S1, BL3 and BT in $24 \mathrm{hrs}$

\subsubsection{Effect of temperature on alcohol fermentation}

Temperature affected ethanol yields, by-products of the fermentation, and aroma of the wine. At the higher temperatures, the yield of ethanol is slightly decreased. Conversely, at a lower temperature, yeast grows slowly. The rate of fermentation increases with increasing temperature up to about $30^{\circ}$ to $33^{\circ} \mathrm{C}$ (Reed \& Nagodawithana, 1991). This study result showed that the suitable temperature for the fermentation of the strains is from 28 to $30^{\circ} \mathrm{C}$ and at $30^{\circ} \mathrm{C}$ the highest yield of alcohol production (Figure 9). According to Luong (2009), this is also a suitable temperature for the development of biomass.

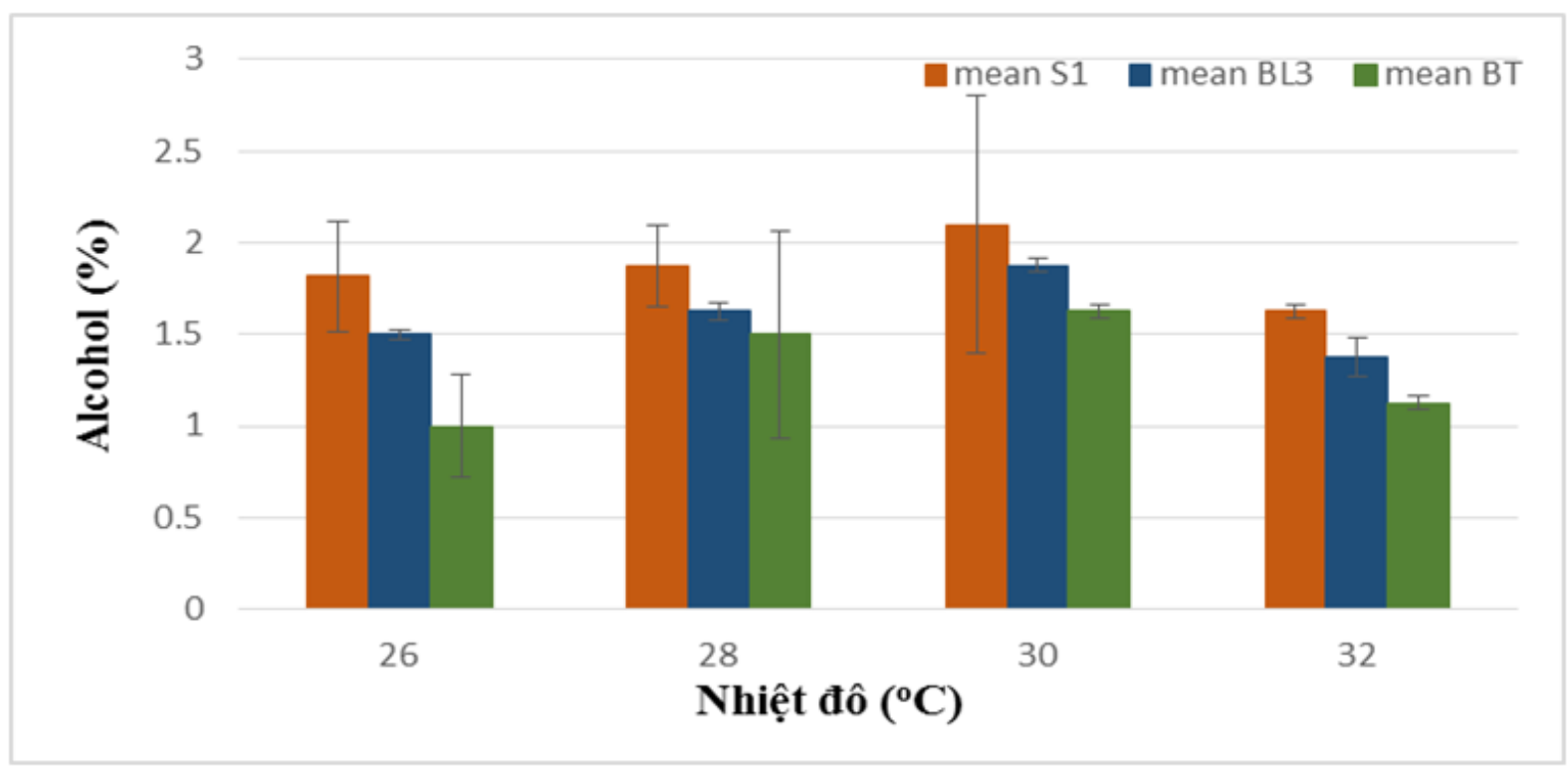

Figure 9. Effect of temperature on the production of alcohol of three strains S1, BL3 and BT for $24 \mathrm{hrs}$. 


\subsubsection{Effect of sucrose concentration on alcohol fermentation}

According to Reed and Nagodawithana (1991), the species S. cerevisiae is capable of using sucrose for growing. In this study, most isolates belong to the Saccharomyces genus and sucrose was used as the sugar source.

Each yeast strain needed a different sucrose concentration to the maximum alcohol production. The strain $\mathrm{S} 1$ produced the highest alcohol concentration $7.8 \%$ in a medium containing 19\% sucrose (Figure 10). Because medium has low ethanol concentrations, the growth of the yeast is inhibited and little growth occurs above 9\% ethanol (Reed \& Nagodawithana, 1991). In the ethanol tolerance test, yeast cells could exist in a medium with high ethanol concentration (19\%) but their metabolism might be inhibited, resulting in reduced fermentation.

In table 3, the concentration of sucrose remaining after fermentation was nearly similar between there strains in all experimented sucrose concentrations, but alcohol concentration was decreased from $17 \%$ or $19 \%$ sucrose (Figure 10). It means that the fermentation process is inhibited when sucrose reaches $21 \%$.

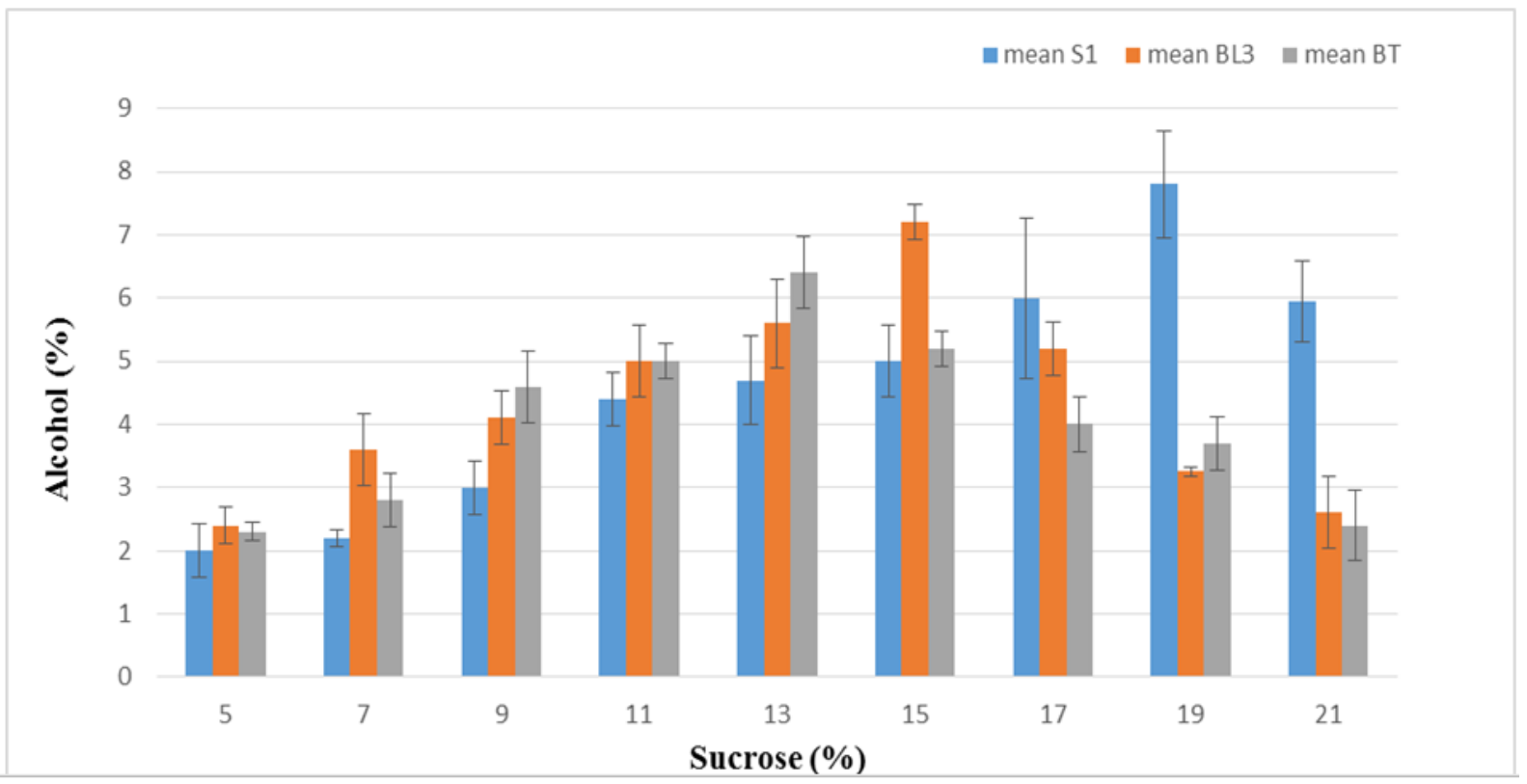

Figure 10. Effect of sucrose concentration to ethanol production of 3 strains S1, BL3 and BT in 5 days

Table 3

The sucrose remained after fermentation

\begin{tabular}{|c|c|c|c|c|c|c|c|c|c|}
\hline \multirow{3}{*}{ Strain } & \multicolumn{10}{|c|}{ Sucrose concentration (\%) } \\
\cline { 2 - 11 } & $\mathbf{5}$ & $\mathbf{7}$ & $\mathbf{9}$ & $\mathbf{1 1}$ & $\mathbf{1 3}$ & $\mathbf{1 5}$ & $\mathbf{1 7}$ & $\mathbf{1 9}$ & $\mathbf{2 1}$ \\
\hline S1 & 3.8 & 3.8 & 3.8 & 3.8 & 3.8 & 3.8 & 3.8 & 3.8 & 3.8 \\
\hline
\end{tabular}




\begin{tabular}{|c|c|c|c|c|c|c|c|c|c|}
\hline \multirow{2}{*}{ Strain } & \multicolumn{10}{|c|}{ Sucrose concentration (\%) } \\
\cline { 2 - 11 } & $\mathbf{5}$ & $\mathbf{7}$ & $\mathbf{9}$ & $\mathbf{1 1}$ & $\mathbf{1 3}$ & $\mathbf{1 5}$ & $\mathbf{1 7}$ & $\mathbf{1 9}$ & $\mathbf{2 1}$ \\
\hline BL3 & 3.8 & 3.7 & 3.7 & 3.8 & 3.7 & 3.7 & 3.8 & 3.7 & 3.8 \\
\hline BT & 3.7 & 3.8 & 3.7 & 3.7 & 3.7 & 3.7 & 3.7 & 3.7 & 3.8 \\
\hline
\end{tabular}

Source: The researcher's data analysis

\section{Conclusion}

In this study, 19 yeast strains belong to the genus Saccharomyces were isolated. There were 4 strains $\mathrm{AD}, \mathrm{HN}, \mathrm{BC} 3$, and $\mathrm{S} 1$ survived in medium with $18 \%$ ethanol. The concentration of sucrose remaining after their fermentation was from 3.77 to $3.80 \%$. The strain $\mathrm{S} 1$ can survive in medium added highest ethanol 18\% and ferment in medium containing $19 \%$ sucrose and generated alcohol was $7.8 \%$ after 5 days cultured. This study could contribute preliminary data for further study of dried traditional yeast in traditional alcoholic beverages and their valuable microorganisms.

\section{References}

Brown, S. W., Oliver, S. G., Harrison, D. E. F., \& Righelato, R. C. (1981). Ethanol inhibition of yeast growth and fermentation: Differences in the magnitude and complexity of the effect. European Journal of Applied Microbiology and Biotechnology, 11, 151-155.

Dung, N. T. P., Rombouts, F. M., \& Nout, M. J. R. (2007). Characteristics of some traditional Vietnamese starchbased rice wine fermentation starters. Food Science and Technology, 40(1), 130-135.

Iwata, H., Suzuki, T., \& Aramaki, I. (2003). Purification and characterization of rice aglucosidase, a key enzyme for alcohol fermentation of rice polish. Journal of Bioscience and Bioengineerin, 95(1), 106-108.

Kofi, E. A., Nout, M. J. R., \& Sarkar, P. K. (2006). Occurrence and function of yeasts in Asian indigenous fermented foods. FEMS Yeast Research, 6(1), 30-39.

Kunkee, R. E., \& Bisson, L. F. (1993). Wine making yeasts. In A. H. Rose \& J. S. Harrison (Eds.), The yeast (2nd ed.). New York, NY: Academic Press.

Kurtzman, C. P., \& Fell, J. W. (1998). The yeast, a taxonomic study. Amsterdam, Netherlands: Elsevier.

Luong, P. D. (2009). Nam men cong nghiep [Yeast industry] (2nd ed.). Hanoi, Vietnam: Khoa học và Kỹ thuật.

Nielsen, S. S. (2010). Phenol-sulfuric acid method for total carbohydrates. In S. S. Nielsen (Ed.), Food analysis laboratory manual. Berlin, Germany: Food Science Texts Series.

Ray, B. (2001). Microorganism used in food fermentation. In B. Ray (Ed.), Fundamental food microbiology. Boca Raton, Fl: CRC Press. 
Reed, G., \& Nagodawithana, T. W. (1991). Yeast technology (2nd ed.). New York, NY: Van Nostrand Reinhold Co., Inc.

Schutz, M., \& Gafner, J. (1993). Analysis of yeast diversity during spontaneous and induced alcoholic fermentations. Journal of Applied Bacteriology, 75(6), 551-458. 